\title{
In Search for Enterprise: State-Sector Reform and Societal Transformation in China
}

\author{
John Hassard, Jackie Sheenan, Jonathan Morris, Xiao Yuxin ${ }^{* *}$
}

With special reference to the steel industry, this article draws upon a politicalinstitutional perspective to examine the progress made in the most recent round of state-enterprise reform in China - the introduction of the Modern Enterprise System and Group Company System. This reform programme is intended, by 2010, to transform 156 of China's largest state-owned enterprises (SOEs) into internationally competitive corporations which, while still remaining in overall state ownership, will much more closely resemble typical Western corporations in their structures and processes, with Boards of Directors accountable to shareholders rather than being subject to the political authority of the Chinese Communist Party (CCP).

Unter besonderer Berücksichtigung der Stahlindustrie wird in dieser Arbeit untersucht, welche Fortschritte in der aktuellen Phase der Reform der Staatsunternehmen in China, also bei der Einführung des "Modern Enterprise System" und des "Group Company System", gemacht wurden. Ziel dieses Reformprogramms ist die Transformation von 156 der größten chinesischen Staatsunternehmen in international wettbewerbsfähige Unternehmen bis zum Jahre 2010. Obwohl die Unternehmen in Staatseigentum bleiben, werden sie strukturell viel stärker an westliche Unternehmen erinnern. Rechenschaft muss dann gegenüber den Anteilseignern abgelegt werden; die kommunistische Partei Chinas wird in diesen umstrukturierten Unternehmen keine politische Autorität mehr ausüben.

\footnotetext{
** John Hassard (*1953), Professor of Organizational Analysis, Manchester School of Management, UMIST; Jackie Sheenan (*1966), Lecturer in History, Department of History, Nottingham University; Jonathan Morris (*1958), Professor of Human Resource Management, Cardiff Business School, University of Wales, Cardiff; Xiao Yuxin (*1964), Lecturer in Operations Management, Sunderland Business School, Sunderland University. Main research interests of all authors include enterprise reform and economic restructuring in China.
} 


\section{Introduction: Researching new models of enterprise reform}

The Modern Enterprise System (MES) and Group Company System (GCS) reform programmes, begun in 1994 and 1992 respectively, are designed to achieve the "corporatization" of SOEs that in the pre-reform era were social and political as much as economic entities. The reform programmes are being piloted in 156 medium and large state enterprises in China, including a number of large steel corporations. 56 of these enterprises are piloting the Group Company System (developing a parent holding company and a large group of subsidiaries, which will have a high degree of management autonomy from the parent), and 100 are involved in the MES programme. In fact, though, the 56 GCS pilots are also undertaking MES reforms internally, so that in effect there are 156 national MES pilot enterprises (Hassard and Sheehan 1997). In addition to these, other firms, including one in the sample, have been selected as pilot enterprises by their provincial governments. Indeed, as it is judged to be an effective strategy for reform, MES-type restructuring is taking place in many companies that are not officially included in any pilot project. This pattern is familiar from previous rounds of reform in China, where "experimental" blueprints have tended already to become general in industry by the time they are formally adopted as official policy, the Contract Responsibility System (CRS) of the 1980s being a case in point (Chen Derong 1995).

The MES reform programme as officially defined consists of three main elements: reform, reconstruction, and restructuring (gaige, gaizao, gaizu). The main elements of the programme are: the clarification of property rights; clearer definition of rights and responsibilities; the separation of government and management functions; and the development of "scientific" enterprise management. In practical terms, the realization of the programme's aims will involve the adoption of new enterprise management mechanisms, technical transformation and improvement, and the reorganization of property rights and assets (Hassard and Sheehan 1997). In general, the GCS programme is intended to create large companies capable of competing in world markets by reorganizing their resources, assets and structure, while the MES is intended to introduce to Chinese SOEs modern management mechanisms and more elements of the Western company system, which is seen by many in China as something which has enabled Western companies to fend off government interference more successfully than their Chinese counterparts. Reducing government interference in enterprise management is thus a primary aim of the MES (Hassard and Sheehan 1997). Another important aspect of the programme is the removal, or at least the substantial reduction, of the social-service burden on enterprises, which is now seen as a major obstacle to SOE profitability and international competitiveness. Traditionally large SOEs in China have been "societies in miniature" (xiao shehui) responsible for the cradle-to-grave welfare of all employees and their dependents. In theory, this significant welfare burden is now to be transferred to local government, but in practice, as will be 
discussed below, this is proving extremely difficult to negotiate, and in only one case in our sample has significant progress been made in this direction). Ultimately, the reforms should enable SOEs to compete within China and abroad on a "level playing-field" with regard to other firms.

\section{Research methodology}

The article is based predominantly on evidence from four rounds of field visits to state-owned steel companies undertaking MES/GCS reforms. These rounds of interviews were conducted on a yearly basis during the period 1995-1998. Ten companies were visited, most on more than one occasion. In the majority of cases, the researchers were allowed to observe operational processes and conduct semi-structured interviews with senior executives, group level managers and engineers. Interview information was collected by way of handwritten notes, although on a few occasions permission was granted for the sessions to be tape-recorded. In addition, one member of the research team (a Chinese national with contacts at each company) arranged a personal "familiarisation meeting" at each plant one month in advance. The reasons for these visits were mainly twofold - first to collect information that would inform the subsequent interview sessions, and second to allow 'sensitive' data - on productivity, performance and manpower levels etc - to be double-checked for accuracy. In addition, the researchers conducted a series of semi-structured interviews with specialists on enterprise reform and economic restructuring in various universities and ministries, plus field visits to companies in other stateowned sectors. In all, 43 interviews were completed during the period of research. Of these interviews, a sub-sample of eighteen have been used as the basis for the present article (see Appendix 1 for details).

\section{A political-institutional perspective}

In line with kindred research on enterprise reform in China (see Chen Derong 1995, Child 1994, Guthrie 1999), the analysis in the present paper is informed by an institutional perspective. On focusing on the political roles played within organizations, the local community, and the State, this perspective could more accurately be described as 'political-institutional'. Such a perspective is appropriate, we feel, because institutional analysis can be related readily to the study of state-enterprise relations in socialist economics. As both Stark and Nee (1989) and Chen Derong (1995) have pointed out, in contrast to earlier theories of totalitarianism and modernisation, institutional analysis presents a clear orienting framework for analysing the economic transition towards a market economy. The primary objective is to understand those regular institutional patterns that explain how economic mechanisms work in reality. Moreover, rather than attempt to understand specific features of a system in reform, institutional analysis attempts to comprehend system processes as a whole. 
Thus, through our interviews, we have attempted to discern how the organization and management of China's SOEs is conditioned by the institutions of that country, especially those of local government and the State. As Child (1994) has noted, Chinese enterprise management reflects institutional politics in ways that are specific to the PRC, with the specificity growing closer the more the enterprise is tied by ownership and control into the state institutional structure. Such processes are particularly apparent in the nonmarketized part of the state sector, which remains to a considerable degree incorporated into the state administrative apparatus. In the present paper we focus on how political-institutional forces influence organizational and management behaviour in those SOEs undergoing MES/GCS reforms. We feel that the emphasis in the 'old' institutionalism (see Di Maggio 1988, Di Maggio and Powell 1991) on the role of power and political processes in the shaping of organization, is crucially relevant to comprehending the 'real' situation in which state-sector Chinese management currently finds itself.

\section{The context: Enterprise restructuring in the state sector}

Traditionally all state enterprises in China, even relatively small ones, aimed for total vertical integration. Since the early 1990s, though, in the interests of specialization, efficiency, product diversification, and clarification of company functions, the steel-making SOEs in our sample have been engaged in a process of industrial fragmentation, mainly separating off all component parts which are involved in their core line of production (i.e. iron and steel) from others which may be engaged in completely unrelated lines of business, working towards the model of a parent holding company with a range of more or less autonomous subsidiary companies. The core iron and steel subsidiaries are to maintain a fairly close relationship with the parent company, although still enjoying some degree of management autonomy, while the other sub-companies, including social-service companies, will have a much higher degree of autonomy from the parent company. The formation of sub-companies serves a number of related purposes. The sub-companies are intended to spread responsibility for results throughout the group, to provide more opportunities for gaining access to capital, especially overseas, and to absorb surplus labour from the core iron and steel businesses. Dividend income from sub-companies (or profit quotas) can be used by the parent company to help cover social welfare costs where these have not been transferred to local government; in addition, since the relationships within the group are now to be governed by market principles, sub-companies will be expected to pay for the provision of social services by the parent company.

All sub-companies will eventually be formed into shareholding or limitedliability companies which will be responsible for their own profit and loss, and which will be able to attract outside investment, borrow from banks, and enter 
into joint ventures with foreign companies in their own right; this ability to attract much-needed outside investment is a primary reason for their formation. A distinction is made between shareholding companies, which are destined for an early stockmarket listing and whose shares can be bought by anyone, including individuals, and limited-liability companies, whose shares can only be bought by institutional investors. These "public-oriented legal persons" (Keun Lee 1996) might be state-owned banks or insurance companies, other SOEs, or state trade unions. In some cases "triangular" debt owed to government bureaux, state-run banks and suppliers has been converted into shares to aid corporations so indebted as to be virtually insolvent in Western terms. Creditors have accepted these arrangements as there seemed little likelihood of recovering any of their money unless some sort of debt write-off was undertaken to enable the corporation to continue in business (Interview 3 1996; Interview 1 1998). Some core iron- and steel-making sub-companies are to remain exclusively funded by the parent company, and the parent company almost always retains a controlling stake of at least $51 \%$, and often much more, in its sub-companies. However, we found examples of parent-company stakes of less than $51 \%$ in one of our case-study corporations, while individual shareholdings could total as much as $20 \%$ (Interview 2 1998).

Sub-companies are responsible for their own profit and loss (although the latter responsibility is sometimes phased in over a period of several years, with a sliding subsidy from the parent company to offset losses which is gradually reduced to nothing). The parent company is only responsible for the money that it has invested in the sub-company, although, as mentioned above, some subcompanies at this stage of the reform are still exclusively funded by the group corporation. In principle sub-companies can decide on their own staffing levels and appoint their own managers (apart from the top one or two posts) without the approval of the parent company. In practice, however, they are expected to consult with the parent company over any large reductions in their workforce. Sub-companies are allowed to recruit new staff from outside the group, but clearly there is also pressure on them to take up the slack where redundant workers in other parts of the group are in need of new posts (Interview 2 1996). More will be said about the question of surplus labour in SOEs later.

The degree of control which sub-companies have over their production targets varies depending on whether the group company is their main customer or whether they sell most of their production outside the group (Interviews 1 and 2 1996). In general they are free to look for markets anywhere, but where they provide a key input to group steel production (such as an iron-ore mining subcompany), the group's orders must be met before production can be sold outside to the highest bidder. Inputs can in theory be bought in from any competitive supplier, but in practice many of our informants observed that it was common for sub-companies to choose to work mainly within existing group relationships whether seeking markets or materials. The parent company was still admitted to 
have considerable influence over most sub-companies whatever the regulations on corporate structure and governance might say on paper (Interviews 1 and 3 1996). The parent company must be informed of all sub-company investment decisions, and must give permission for any investment above a certain amount; at one steel corporation for which we have figures, the investment ceiling for sub-companies is RMB 30 million (about $£ 2.25$ million).

Below we draw upon a political-institutional perspective to comment on several key aspects of the MES and GCS programmes as these have developed to date in the Chinese steel industry. Attention is paid not only to the questions of relations between state organs and enterprise structures and processes, but also to the issue of shareholding and the problem of surplus labour, as these are important and politically problematic areas of reform at present.

\section{MES and GCS reforms in practice: A political-institutional view}

China has won praise for its gradualist, pragmatic reform path since 1978, particularly in comparison with the countries of Eastern Europe and the former Soviet Union (EEFSU) (Child 1994; Nolan 1995). But successful though it has been to date, the reform programme has now come to the point where all the relatively easy and less controversial steps have been taken. Still to be tackled are much more difficult and politically sensitive issues such as employment restructuring, ownership, and SOEs' relationships with central and local government. The very nature of the SOE in pre-1978 China means that this stage of reform is inextricably bound up with other wide-ranging reforms such as the abolition of subsidized housing and the effort to set up an urban welfare state in China under local-government auspices. It is also occurring at a time of economic difficulty throughout the region. Some of the corporations in our study are finding themselves having to compete for domestic business with Japanese and Russian firms as these seek new markets to replace those lost in Southeast Asia, at the same time as they themselves are having to look for new export markets for the same reason; the resulting price competition has reduced profit margins which were often not generous to begin with (Interview 2 1998).

Aside from these unexpected external factors, institutional problems of ideology and politics are still hindering further progress in state-enterprise reform. Change has generally gone furthest in those areas that are purely internal to the corporation, although even here the influence of existing power structures remains strong in many respects. Superficially at least, MES enterprises in China do now more closely resemble typical Western corporate structures. The steel corporations in our sample now generally have a Board of Directors chosen by shareholders which selects the general manager. But for large, stateowned steel-makers, in most cases the sole shareholder is still the state, which means that in practice candidates for the Board are recommended and appointed by the government, i.e. the CCP, just as top enterprise managers always were 
before the reforms. It was admitted in two of the corporations we visited that changes in corporate structure were still more form than substance to date, with the ideal of shareholder control falling prey to continued direct government interference. The reportedly high level of government interference in the appointment of Boards of Directors thus has so far negated one of the main purposes of the MES programme, the separation of government and management functions. There are no indications that this problem will be resolved in the near future.

Similar problems have arisen with attempts to alter the distribution of power within the enterprise. Before the reforms, institutional power mainly rested with the so-called "old three committees", the party branch, management, and the official trade union. Under the MES, these are to be replaced by the "new three committees": the Board of Directors, the Board of Supervisors, and the Shareholders' Congress. If it were carried out as intended, this reform would directly attack the vested interests of many in the old structure, notably the party and the official trade union, generating resistance. Under the MES, the Board of Directors ought to be the highest level of decision-making, but this was always the role of the party in the past, and the party is proving reluctant to give up its power. Many enterprises, including some in the steel industry, have therefore fudged the issue by appointing the branch party chairperson as chair of the Board of Directors as well, so that the same person can give orders wearing either "hat". Similarly, existing managers have been transformed into a new "Board of Directors" by a stroke of the pen, and party and union organizations have also found a place on the Board of Supervisors, allowing power to remain in essentially the same hands within the enterprise but under different titles. The question of how to break up the old vested interests in state-owned industry has been described to us as a "forbidden area" of reform, since it touches on the question of the role of the CCP in a mixed economy and the 'proper' limits of its political-institutional power.

Far from operating on a level playing-field, SOEs in China are still subject to varying treatment from central and local authorities according to their particular status and history, as well as being affected by regional policy variations (Solinger 1996; Goodman 1997). The crucial role of local government can be seen in the very selection of SOEs as reform pilots. One corporation in our sample was co-opted as a national GCS pilot against its own preferences (Interview 5 1996), and several have been compelled by local government to absorb into the group smaller, loss-making companies which would otherwise have gone bankrupt, throwing their employees out of work (Interview 5 1996; Interview 2 1998). The finances of these autonomous sub-companies are kept separate from those of the parent company, so only limited financial help will be forthcoming from the parent if the sub-companies continue to make losses. Therefore little benefit is gained from this shifting around of unprofitable enterprises by anyone except local government, which divests itself of the 
responsibility for the small enterprises' losses and has wage payments guaranteed by the group corporation (late payment or non-payment of wages being a major cause of labour unrest in China in the 1990s (Sheehan 1996; 1998)). Local government also tends, for obvious reasons, to favour those enterprises under its control over those which come directly under the authority of a central government department or bureau, leading the latter to complain that they need more "government interference", not less, as long as they are not competing on equal terms in a well-established and properly regulated market economy (Interview 1 1998).

\section{Shareholding: Privatization by any other name?}

At the firm level, many state-sector managers are prepared to discuss quite openly the extent to which their subsidiary companies, welfare services, company housing etc. have been or will be privatized, but the word is still seldom heard in the speeches of the top party leadership, except in assertions that privatization is not an option for China's largest state-owned corporations in the foreseeable future. Despite the announcement by President Jiang Zemin at the 15th CCP Congress that all but about 500 of the largest and most strategically significant SOEs would henceforth have to make their own way in the market, and would face merger, bankruptcy or closure if they could not make a profit, any degree of privatization of elements of the largest state-owned corporations remains extremely controversial even as it begins to happen on the ground. Thus some of the group corporations in our sample are finding that they have successfully carried out their internal corporate restructuring to establish viable sub-companies with their own "legal-person" status, only to face difficulty in getting permission for the listings which would bring in vital new funds for investment. Where listings (on the Hong Kong, Shanghai and Shenzhen exchanges) have taken place, they have often been of sub-companies that cannot be identified as part of the parent corporation from their names. One of our case-studies has taken a different tack, gaining permission for a listing of just two of its more than a dozen core iron-and-steel sub-companies, but under such a general company title that any and all of the other elements of its steel-making operations could be added to the listing in future (Interview 2 1998). In part this course is intended to avoid too ambitious a listing at a time of great volatility in the region's stock-markets, but in the main it is a product of central-government reluctance to countenance creeping privatization in some of its most strategically and ideologically significant corporations.

\section{Surplus labour and political stability}

In May 1997 the State Commission for Economic Restructuring (SCER) predicted that 15-20 million surplus workers in the state sector would lose their jobs by 2000 , and in turn estimated the total number of surplus workers in SOEs 
at 54 million, close to half of the total work-force. The proportion of surplus labour in SOE workforces varies across enterprises and is affected by factors such as enterprise size, industrial sector, and geographical location. Our casestudy enterprises initially planned to reduce their core work-forces by between 15 and 50\% during the period of the Ninth Five-Year Plan (1996-2000) (Interviews 2, 3 and 4 1996), although at least one has since extended the deadline to 2003 (Interview 1 1998). This level of surplus employees is in line with the findings of other surveys of the same sort of large SOE (Kuehl and Sziraczki 1995: 75). Clearly the numbers involved are substantial, and the problem of how to deal with such a high level of overmanning is one which still largely falls to SOEs themselves to solve (Lin and Sziraczki 1995: 28), with only limited help from local and national government.

The corporations concerned need to make these cuts in the workforce to reduce their costs and improve their productivity in order to compete both nationally and internationally. It is no exaggeration to say that the continued success of the present reform programme depends on the reductions going ahead, yet, at the same time, the single overriding priority of the central government is still the maintenance of social and political stability in China (and of course the maintenance of its own power), and this is already being threatened by state workers' reaction to downsizing and the threat of redundancy. SOE managers are fully aware of the tremendous responsibility they bear in this area, and they have prepared as best they can to achieve the very large-scale redundancies required while keeping serious unrest and resistance to a minimum. The watchword for this part of the reforms is "making a channel before the water comes"; in other words, have acceptable destinations ready before workers lose their existing jobs.

China still cannot really be said to have a functioning labour market to date (Warner 1995: 161; Child 1994: 162), despite the increased flexibility which both enterprises and individuals have gained in an era of widespread contract employment and some enterprise autonomy over the recruitment of employees. Some large SOEs have been replacing contract workers at the end of their contracted period of employment with otherwise redundant permanent workers from within the group (Interview 2 1996), but given the relatively small proportion of such contract employees in the state work-force as a whole (Warner 1995: 161), this is not a viable method in itself of making the large cuts in core employment which are planned. Aside from this minority of lesssecurely employed workers, none of our case-study corporations has yet been prepared to force out any employee who was not willing to go. Instead they have sought to develop internal labour markets that will offer retraining and reallocation within the group to workers, or will help them to find alternative employment or self-employment outside the group. Workers are being shifted out of overmanned core production units and into new sub-companies set up for the purpose of absorbing surplus labour (Kuehl and Sziraczki 1995: 66; Hassard 
and Sheehan 1997: 92-93; Interviews 1 and 3 1997). Many large state-owned corporations now typically contain within them sub-companies running such businesses as shops, hotels, restaurants and travel agencies, as well as socialservice companies and companies engaged in any kind of manufacturing or service provision where profits can be made. Considerable numbers of workers are involved in these shifts: in one of the large state-owned steel companies studied by the authors, the number of employees transferred out of core ironand steel-producing units into sub-companies now exceeds the number remaining in iron and steel production by 40\% (Interview 4 1996).

Some large SOEs have set up labour pools for surplus employees where they can undergo re-training for vacant posts elsewhere within the group (Interview 1 1996). Surplus workers may remain in the group labour-pool for up to two years, but ultimately their employment can be terminated by the corporation if no suitable post is found for them within that time (Hassard and Sheehan 1997: 93). Alternatively, they may retain their employment status within the enterprise once the two-year period in the labour pool has passed, but instead of continuing to receive their basic salary, they are only paid the monthly amount calculated by the local government as the minimum necessary to cover basic living expenses (Interview 3 1996). This is an example of the proliferation of different forms of employment status within the firm through which unambiguous dismissal of surplus workers is being avoided. One of our casestudies has an alternative system whereby redundant employees are transferred to an in-house "job-centre" which provides retraining and job information. The company will be responsible for three years' basic living expenses for these staff and they will be offered two alternative posts within the firm, but if they turn both of these posts down, the company will have no further responsibility for them (Interview 2 1998). Again, compulsory termination of employment is implicit in this scheme, although it has not yet happened to any employee.

In many large SOEs a range of employment forms has thus been developed which includes not only permanent waged employment, retraining and redeployment within the firm, voluntary severance, and early retirement, but also stages in between. At one of the large steel plants visited by the authors, surplus workers' options include "retirement within the company", in which they remain in post with no annual increases in pay; alternatively, they may remain in post without pay but retaining their status as an employee of the unit. This retention of a formal link with the work-unit has security benefits for the workers concerned, allowing them, for example, to remain in unit-owned housing at low rents while obtaining work elsewhere or becoming selfemployed. The alternative to retaining such a link is known as the "two don't look fors" (liang bu zhao), meaning that the worker will not look for any further help from the unit, and the unit has no further call on its former employee. The various forms of employment status now in existence in the state sector account in part for the discrepancy between China's official urban unemployment rate 
(which still stands at around 3.5\%), and the much higher figures routinely given by academic analysts and even the official trade unions in China, which include the large numbers of workers who have retained some sort of formal relationship, paid or unpaid, with their work-unit but are not actually going to work. Estimates for the proportion out of work based on this definition range from $8 \%$ to $15 \%$, with even higher local rates cited in parts of the northeast which have concentrations of large and loss-making SOEs.

Besides creating vacancies elsewhere within the enterprise for surplus workers and restricting entry from outside the group, large SOEs are also attempting to increase the number of workers exiting from the group (Kuehl and Sziraczki 1995: 68). One major method of doing this is to encourage and facilitate early retirement (Interview 2 1996, Interview 2 1998). In some cases employees taking advantage of early-retirement schemes can receive a lump-sum investment from the group company in order to help them start up their own business. To make voluntary severance for workers of any age more attractive to those wishing to change jobs or go into business on their own, the requirement on these employees to pay back the costs of their training if they leave the corporation has been removed (Interview 3 1996). Inevitably, companies have found that it is not necessarily the right employees, from the enterprise's point of view, who volunteer for this sort of scheme, and some have had to introduce various incentives to ensure the retention of key technical personnel in particular (Interview 3 1996). To help absorb the increasing numbers of redundant SOE employees, some cities have reserved certain new jobs or self-employment permits, or even entire lines of work, for them. In Beijing certain occupations, including accountants, secretaries, bus-conductors, and sales-clerks, have been reserved for permanent city residents rather than rural migrants in an attempt to vacate tens of thousands of posts for laid-off urbanites. The municipal government has also reserved 20,000 taxi licenses for laid-off workers, asking bankrupt SOEs in the capital to submit lists of recommended workers for this scheme. Beijing's programme in turn is modelled on that of Shanghai, which has pioneered efforts to help surplus workers from SOEs go into business on their own by easing registration procedures and offering tax holidays to new small businesses. This type of programme, however, conflicts with the new market ethos which dictates that the established working class must now compete with migrants from the countryside for the available work, and there is thus conflict among policymakers about how far the old state-sector workforce can or should be protected from the rigours of the market.

Although the institutional role of government in determining SOEs' levels of employment has been reduced under the reforms (Hay et al 1994: 130-131), local governments and labour bureaux do still have some influence or authority in some respects (Lin and Sziraczki 1995: 17), and some managers in large SOEs continue to complain of government interference in areas where they have 
autonomy on paper. Large SOEs are still sometimes compelled to employ workers (often those laid off by other enterprises) whom they do not need or want, or loss-making enterprises are merged with more successful ones against the latter's will in order to safeguard jobs in the struggling firm (Kuehl and Sziraczki 1995: 65; Interview 4 1996). Some enterprises seem better able than others to fend off unwanted impositions of this kind by local government, either because of variations in policy between different cities or regions, or because of the particular circumstances of the enterprise concerned and its past relationship with local authorities (Interviews 5 and 6 1996; Solinger 1996).

Since 1995 the Labour Law has, however, shifted some of the responsibility for helping the unemployed to find work onto local government institutions rather than leaving enterprises to bear the whole burden (Interview 3 1996). The national government in 1997 also introduced a period of one to three years' compulsory training for all new entrants to the labour force, a measure intended to ease employment pressures.

\section{Labour unrest and the threat to stability and reform}

The caution exhibited to date by management in large SOEs when dealing with workforce reductions is understandable. The prospect of labour unrest fuelled by discontent over job losses and other aspects of China's economic reforms is a real one, and in fact such unrest is already beginning to occur, although it is much more common among the ex-employees of small and medium SOEs that those of the large corporations with which this research is mainly concerned. Lacking the resources to "make the channel before the water comes", smaller SOEs tend instead to make abrupt announcements regarding merger or bankruptcy which are received by their workers with anger and resentment, and which not infrequently result in street protests and factory sit-ins (Morris et al 1998; Sheehan 1998). Incipient unrest is not confined to the employees of small SOEs, however. Core, permanently-employed state-sector workers were traditionally regarded as the least restive segment of the Chinese working class under CCP rule, but by the end of the 1980s this had changed. State workers were in the vanguard of the 1989 democracy movement as a newly aggrieved group suffering significant relative deprivation under the reforms and angry in particular about high levels of official corruption and inflation (Walder and Gong 1993; Sheehan 1998), and there is every likelihood of further protest from them as the long-perceived threat to their vital interests posed by economic reform finally materializes.

Managers in these large state-owned corporations have thus put considerable effort into justifying the planned reductions and persuading workers to accept them. Firstly, they stress the new opportunities available to some workers in the new reform environment. This is more than institutional propaganda: the chance to change jobs, and in particular to set up in business independently, is 
genuinely welcomed by some state employees. Success stories of former SOE workers making their fortunes are widely publicized in an attempt to overcome workers' fears of losing the security of permanent state employment, with some success (Interviews 2 and 4 1996). It is plain to all involved, however, that not everyone who leaves state employment is going to do better elsewhere (Warner 1995: 162). The managers' task then is to convince employees that some have to leave the enterprise if any are to prosper, as in the new "market socialist" environment enterprises cannot continue to carry present levels of surplus labour indefinitely while attempting to restructure themselves to compete in national and world markets (Interviews 1, 2 and 4 1996). This approach seemed initially to have been relatively successful, if not in whipping up real enthusiasm for down-sizing among state employees, then at least in engendering a mood of resigned acceptance of the end of the "iron rice-bowl" for some (Interviews 2 and 4 1996; Warner 1995: 132).

However, in the last two years unrest has become so widespread, if still mainly local and sporadic, that it has become one of the major concerns of the top leadership and threatens to cause a significant slowing in the implementation of many reform programmes, such as planned housing reform. In internal discussions, laid-off workers have been identified as the third most serious threat to political stability in the People's Republic, after separatists in the Muslim northwest and the Tibetan independence movement, with the resort by workers to the organization of independent unions a particular cause for concern. Local governments are coming under even greater pressure from the centre to provide alternative employment or retraining and emergency living allowances to unemployed workers in order to stave off more widespread unrest, and have been particularly warned not to divert government money intended for these purposes to other uses. Local governments are even authorized to make extra payments to workers in areas or at enterprises with a particular record of unrest, setting a dangerous precedent of rewarding those who make the most trouble (Sheehan 1996: 555). Large state-owned corporations are thus more aware than ever that, at least until a reasonably complete, functioning alternative welfare system is in place, they will not in fact be able to expect society to absorb the large proportion of surplus labour within their workforces.

Most of our case-study corporations are still only at the stage of holding preliminary discussions with local government about divesting themselves of their welfare responsibilities. If the transition from enterprise-based to localauthority welfare proves a successful one in the only case-study city where this has been attempted to date, it might encourage other local governments to work more actively in this direction. But at present, many of the firms in this study are quite pessimistic about the prospects of freeing themselves of this historical burden, both because of the simple inability of society to cope with such a transfer in this period of regional economic crisis, and also because of 
resistance from their own staff, who fear a reduction in the quality of their schools, for example, if these are taken over by hard-pressed local authorities who already have "their own" schools to fund and look after (Interviews 2 and 4 1998). A number of our case-study corporations contain within them some of the best schools in their area, nationally recognized for their quality, and thus it is understandable that despite their awareness of the economic burden which running such services constitutes on a modern industrial corporation, employees are still reluctant to see their firms abandon what has often been very successful social provision.

\section{Conclusions}

This paper has examined the development of MES and GCS reforms in the steel industry through a perspective that highlights the associated politicalinstitutional relationships of communities, enterprises and organs of the state. This perspective has offered a lens for interpreting and explaining the relative inertia experienced in the latest stages of enterprise restructuring and economic reform. Our data suggest that devices such as internal labour markets and local labour pools appear to offer a socially accepted pattern, possibly informally institutionalised, for dealing with the problems of downsizing.

Faced with the scale of such difficulties as the surplus labour problem, it is easy to become perhaps over-pessimistic about the prospects for reform. Given China's record to date of gradual, pragmatic transition away from a planned economy, in contrast to the "big bang" approach of many EEFSU countries, the recent signs of slowing of reform in response to rising labour unrest may actually be encouraging ones, as they show, institutionally, that the national leadership has recognized the scale and seriousness of the problems reform has engendered and is now proceeding more cautiously. It is also true to say that China since the early 1980 s, after its post-Cultural Revolution peak of youth unemployment which coincided with the early-1980s recession, has had a very good record in job creation, particularly in the non-state sector. However, the unusually high growth rates which have enabled this job creation to take place have been slowing for several years and are likely to be further reduced by the regional economic crisis (and also by 1998's natural disasters in the provinces worst affected). In addition, the number of redundant workers who will have to leave the state sector in the next few years is without precedent.

The SOEs in our sample are faced with a frustrating dilemma. Above all, if they are to be able to complete their restructuring and technical transformation in the next few years, they need to make very large reductions in their core workforces and in order to lower costs and raise productivity. There are substantial markets within China presently filled by imports which could be tapped by these large corporations if the investment were available to enable them to restructure their production accordingly (Interview 2 1998). Yet the 
requirements of further state-enterprise reform are now in sharp conflict with the government's top priority of political and social stability and the avoidance of an obvious change in the ownership status of the largest state-owned corporations, and the SOEs in our sample are presently unable to do much more except reform internally as far as they are able while waiting for a change in the policy environment which would enable them to take the next steps.

\section{References}

Chen Derong (1995), Chinese Firms Between Hierarchy and Market. London: St. Martin's Press.

Child, J (1994), Management in China During the Age of Reform. Cambridge: Cambridge University Press.

Di Maggio, P J (1988) “Interest and Agency in Institutional Theory”. In L G Zucker (ed) Institutional Patterns And Organizations. Cambridge, MA: Ballinger

Di Maggio, P J and Powell, W W (1991) “Introduction”. In W W Powell and P J Di Maggio, The New Institutionalism in Organizational Analysis, Chicago: University of Chicago Press

Goodman, D S G (ed.) (1997), China's Provinces in Reform. London: Routledge.

Guthrie, D (1999) Dragon in a Three-Piece Suit, New Jersey: Princeton University Press

Hassard, J, and J Sheehan (1997), "Enterprise reform and the role of the state: The case of the Capital Iron and Steel Works, Beijing." In A Bugra and B Usdiken (eds.), State, Market and Organizational Form. Berlin: Walter De Gruyter.

Hay, D A, D J Morris, G Liu and Shujie Yao (1994), Economic Reform and State-owned Enterprises in China 1979-1987. Oxford: Clarendon Press.

Kuehl, J, and G Sziraczki (1995), "Employment restructuring at micro-level: Results of the Dalian pilot enterprise survey." In Lin Lean Lim and G Sziraczki (eds.) Employment Challenges and Policy Responses: Chinese and International Perspectives. Beijing: International Labour Office, Area Office Beijing.

Lee, Keun (1996), "An assessment of the state sector reform in China: Viability of 'legal person socialism'." Journal of the Asia Pacific Economy 1, 1, 105-121.

Lin Lean Lim and G Sziraczki (1995), "Introduction." In Lin Lean Lim and G Sziraczki (eds.) Employment Challenges and Policy Responses: Chinese and International Perspectives. Beijing: International Labour Office, Area Office Beijing.

Morris, J, J Hassard and J Sheehan (1998), "Muddling through the wreckage: State-owned enterprises and the economic reform process in China." Keele-China Management Centre Working Paper 2, University of Keele.

Nolan, P (1995), China's Rise, Russia's Fall: Politics, Economics and Planning in the Transition from Stalinism. London: Macmillan.

Sheehan, J (1996), "Is there another Tian'anmen uprising in the offing?" Jane's Intelligence Review 8, 12: 554--556.

Sheehan, J (1998), Chinese Workers: A New History. London: Routledge. 
Solinger, D J (1996), "Despite decentralization: Disadvantages, dependence and ongoing central power in the Inland: The case of Wuhan", China Quarterly 145, 1-34.

Walder, A, and Gong Xiaoxia (1993), "Workers in the Tian'anmen protests: The politics of the Beijing Workers' Autonomous Federation." Australian Journal of Chinese Affairs 29 (January 1993), 1-29.

Warner, M (1995), The Management of Human Resources in Chinese Industry. London: Macmillan.

\section{Appendix 1}

Interview 11995 was conducted on 30 August 1995 with a senior academic expert on management and fiscal science based in Beijing.

Interview 21995 was conducted on 1 September 1995 with a senior specialist in economic management at a leading Chinese Communist Party academic institution.

Interview 31995 was conducted on 4 September 1995 with an economic specialist working in the Metallurgical Industry Ministry in Beijing.

Interview 41995 was conducted on 4 September 1995 with a senior member of staff specializing in research and development at a large steel corporation in Beijing.

Interview 51995 was conducted with several senior managers from a non-steel state-owned corporation near Beijing.

Interview 11996 was conducted on 6 August 1996 with two group-level directors at a large steel corporation in eastern China.

Interview 21996 was conducted on 7 August 1996 with two group-level managers responsible for Human Resource Management and the plant CCP Party branch respectively at the same east China steel corporation.

Interview 31996 was conducted on 9 August 1996 with an engineering specialist and former group director of a long-established steel corporation in west-central China.

Interview 41996 was conducted on 14 August 1996 with a group-level manager previously responsible for enterprise restructuring and now working in economic research and development, and another senior member of the economic research and development institute of a large steel corporation in central China.

Interview 51996 was conducted on 15 August 1996 with a senior academic management specialist from a University of Metallurgical Science and Technology in central China.

Interview 61996 was conducted on 19 August 1996 with senior group-level managers from a large steel corporation on China's eastern seaboard.

Interview 11997 was conducted on 15 August 1997 with the chief engineer and manager of a large steel corporation in Beijing.

Interview 21997 was conducted on 25 August with senior group-level managers from a large steel corporation in southwest China. 
Interview 31997 was conducted on 27 August with several group-level managers from a large steel corporation in south China.

Interview 11998 was conducted on $4^{\text {th }}$ August 1998 with several top managers of the steelworks visited for Interview 31996.

Interview 21998 was conducted on $11^{\text {th }}$ August 1998 with two senior managers from the steel-works visited for Interview 41996.

Interview 31998 was conducted on $14^{\text {th }}$ August 1998 with a group of top-level managers from the steel-works visited for Interview 61996.

Interview 41998 was conducted on $7^{\text {th }}$ August 1998 with two senior managers from the steelworks visited for Interview 21997. 